\title{
The Effect of Rainfall Characteristics and Tillage on Sheet Erosion and Maize Grain Yield in Semiarid Conditions and Granitic Sandy Soils of Zimbabwe
}

\author{
Adelaide Munodawafa \\ Department of Land and Water Resources Management, Midlands State University, P.O. Box 9055, Gweru, Zimbabwe \\ Correspondence should be addressed to Adelaide Munodawafa, munodawafaa@msu.ac.zw
}

Received 4 November 2011; Revised 15 January 2012; Accepted 16 January 2012

Academic Editor: María Cruz Díaz Álvarez

Copyright (C) 2012 Adelaide Munodawafa. This is an open access article distributed under the Creative Commons Attribution License, which permits unrestricted use, distribution, and reproduction in any medium, provided the original work is properly cited.

In semiarid regions, rainfall is one of the primary factors affecting soil erosion and crop production under rain-fed agriculture. The study sought to quantify the effect of rainfall characteristics on sheet erosion and maize grain yield under different tillage systems. It was carried out under semiarid conditions and infertile sandy soils of Zimbabwe. Rainfall amount and intensity were recorded every 24 hours, while sheet erosion was measured from four tillage systems (Conventional Tillage (CT), Mulch Ripping (MR), Tied Ridging (TR) and Bare Fallow (BF)). Maize (Zea mays L.) was grown on three tillage systems (CT, MR, and TR). Rainfall amount varied significantly $(P<0.001)$ between seasons $(164-994 \mathrm{~mm})$. CT recorded the highest average soil losses (15t/ha), while MR and TR recorded 1.3 and $1.2 \mathrm{t} / \mathrm{ha}$, respectively. Maize grain yields increased with increasing seasonal rainfall giving yield-responses of $0.9 \mathrm{t} / \mathrm{ha}$ (TR) to $1.3 \mathrm{t} / \mathrm{ha}(\mathrm{MR})$ for every $100 \mathrm{~mm}$ rainfall increment. Overall, treatments didnot differ significantly $(P<0.497)$, except during drier seasons $(P<0.025)$. Regression equations showed that yields can be confidently predicted using rainfall amount and time, with $R^{2}$ values of 0.82 to 0.94 . Maize grain yields proved to be mostly dependent on rainfall amount than fertility. The productivity of the soils decreased with increased length of cultivation.

\section{Introduction}

Rill and gully erosion in the smallholder areas of Zimbabwe is largely under control through mechanical conservation structures such as contour ridges, grassed waterways, and storm drains [1]. However, sheet erosion is still a major threat to soil fertility and productivity. The sheet erosion process is selective and deprives the soil of its fine particles (clay and organic matter) [2]. These particles are easily splashed out and carried in suspension, while the heavier particles remain behind [3-5]. The soils are thus impoverished as these nutrient reservoirs are lost together with inherent and applied plant nutrients. The bulk density of the soils is increased and plant available water is decreased. According to Stocking and Peake [6], the changes in soil conditions, in many cases, may be describing the effect of erosion induced low soil productivity.
In soil erosion research, rainfall amount and intensity (erosive power of rainfall) have been found to be the fundamental factors affecting soil erosion $[7,8]$. The impact of raindrops on the soil surface results in temporary capping of the soil and lowered infiltration rate, thus generating runoff [9-11]. Runoff is directly dependent on rainfall amount and intensity and soil loss, being a function of runoff also depends primarily on these factors. According to Morgan [12], sheet erosion occurs when, during a rainstorm, soil moisture storage and/or the infiltration capacity of the soil are exceeded.

Rainfall is also the primary factor affecting crop production in rain-fed agriculture [5]. Previous studies in semiarid regions have shown that the yield parameter is mainly dependent on the amount and distribution of rainfall. Elwell [13] found a linear relationship between rainfall amount and yield on granitic sands and high rainfall conditions of 
Zimbabwe, where yield increased proportionally to rainfall amount. The soil type also influences crop production as determined by the fertility level as well as the soil physical characteristics. The crop production potential of granitic sandy soils is low, but if adequate fertilisers are applied, average yields can be achieved [14]. However, the fertiliser application is very much dependent on rainfall, so that rainfall becomes the most important factor influencing crop production. Mid-season droughts are common in the semiarid areas due to the erratic nature of rainfall and the soils' low water holding capacity [15]. Rainfall distribution becomes an important factor if the effect of these mid-season droughts is to be minimized.

While it is generally known and acceptable, that rainfall (amount, intensity, and distribution) affects soil erosion and productivity, the principle cannot be applied everywhere successfully. Kaihura et al. [16] stated that the rates and the effects of erosion are dependent on the soil type and agroecological conditions. Thus, it is important to define the factors that affect soil erosion in different regions by developing equations that estimate soil erosion and productivity to cover areas of the same climatic and ecological conditions. These equations should, however, be simple and straight forward enough to be of benefit to the farmers. The objective of these equations should be to use some important and easily measurable variables to predict parameters of agricultural production. Thus from either a crop production or soil erosion/conservation point of view, rainfall characteristics and distribution are of importance if farmers are to successfully manipulate the soil and reduce the destructive potential of tropical storms. The objective of this study is, therefore, to determine the rainfall characteristics that affect soil erosion and maize grain yield. This study, therefore highlights the conservation potentials of different tillage systems under the semi-arid conditions of Zimbabwe. Furthermore, simple soil loss, runoff, and yield equations showing the most important factors that affect these parameters are developed.

\section{Materials and Methods}

2.1. Experimental Site. Zimbabwe lies well within the tropics but its climate is subtropical, being moderated by altitude. Its climate is thus classified as temperate (mild mid-latitude), with dry winters and hot summers (Cwb) according to the Koeppen climate classification system [17]. The average temperatures rarely exceed $33^{\circ} \mathrm{C}$ in summer or drop beyond $7^{\circ} \mathrm{C}$ in winter [18]. The country has been classified into five agroecological regions, namely, Natural Regions I, II, III, IV, and V. Only Natural Regions I and II have relatively high effective rainfall and are suitable for intensive agricultural production. Natural Regions III, IV, and V constitute $83 \%$ of the total land area (92\% of small-holder farming area) and are not suitable for intensive, high input agriculture [15]. Zimbabwe's soils are predominantly derived from granite and the clay content of these soils varies according to the degree of weathering (influenced by rainfall) and catenal position $[19,20]$. From among all the soils derived from granite, the sandy soils, of the fersiallitic group, comprise the majority, about $70 \%$ of the land area [19] and are dominant in the small-holder farming areas [21]. The agricultural potential of these soils is fair [20], and their productivity is likely to decline under intensive continuous cropping.

The study was carried out at Makoholi Research Station situated $30 \mathrm{~km}$ north of Masvingo town, which is the regional agricultural research centre in the medium-to-low rainfall areas. The station lies at an altitude of about $1200 \mathrm{~m}$, within Natural Region IV with an average annual rainfall of 450$650 \mathrm{~mm}$. Characteristic of this region is the erratic and unreliable rainfall both between and within seasons [22]. The soils are also inherently infertile, pale, coarse-grained, granite-derived sands, (Makoholi 5G) of the fersiallitic group, Ferralic Arenosols [19, 23]. Arable topsoil averages between 82 and 93\% sand, 1 and 12\% silt, and 4 and $6 \%$ clay $[21,24]$. The small amount of clay present is in a highly dispersed form and contains a mixture of $2: 1$ lattice minerals and kaolinite [23]. The organic matter content is also very low, about $0.8 \%$, while $\mathrm{pH}\left(\mathrm{CaCl}_{2}\right)$ is as low as 4.5 . The soils are generally well drained with no distinct structure [24], but some sites have a stone line between 50 and $80 \mathrm{~cm}$ depth. The high infiltration rate and low water holding capacity are due to the soil texture characteristics.

2.2. Experimental Design and Treatments. The treatments were laid out in a randomised block design replicated three times. Four tillage systems were considered, conventional tillage, mulch ripping, tied ridging, and bare fallow. Conventional tillage is the most widely used tillage practice in the small-holder farming areas of Zimbabwe constituting 73$90 \%$ of the cultivated area [25]. The remainder of the land is ploughed using hired tractor $(5-25 \%)$ and less than $1 \%$ is under tillage systems that conserve soil, moisture, nutrients and/or energy inputs [25]. Mulch ripping and tied ridging systems have a great potential in conserving soil and water and are being promoted in a bid to effectively manage the natural resources and sustain productivity.

Tillage for the different systems was carried out as follows: conventional tillage (CT): ploughed to $23 \mathrm{~cm}$ using an ox-drawn mouldboard plough; mulch ripping (MR): crop residues were left to cover the ground and only rip lines were opened between the mulch rows, $25 \mathrm{~cm}$ deep, using a ripper tine; tied ridging (TR): $20 \mathrm{~cm}$ high crop ridges were laid out at $1 \%$ slope and were $90 \mathrm{~cm}$ apart. Ties were constructed in the furrows at $1-1.5 \mathrm{~m}$ intervals to create microdams. Bare fallow (BF): tractor ploughed and kept crop and weed free throughout the season. Maize (Zea mays L.) is the staple food in Zimbabwe and is planted on $>70 \%$ of all cultivated land in the small-holder sector. Thus maize was planted on all plots, except BF, at a population of 36000 plants/ha. Optimal recommended fertiliser rates were applied at recommended times. For yield assessment, two subplots of $3.6 \times 6 \mathrm{~m}$ were marked out on CT and MR plots, while four subplots were marked out on TR. Rainfall was measured every 24 hours, using standard and autograghic rain gauges.

2.3. Collection of Runoff and Sediments. The standard soil erosion methodology for Zimbabwe was used [26, 27], where 
the plots were laid out at $4.5 \%$ slope. Erosion plots measured $30 \times 10 \mathrm{~m}$ for CT, BF, and MR and $150 \times 4.5 \mathrm{~m}$ for TR. Surface runoff and soil loss from each plot were collected at the bottom of the plots in 1500 litre conical tanks. The tanks were emptied daily and soil loss and runoff quantified [28]. The collection tanks were calibrated and runoff was measured using a metrestick. Once the first tank was full its overflow passed through a divisor box with ten slots, which channelled only one-tenth of the overflow into the second tank. Nine-tenths of this overflow was allowed to drain away, thus increasing the capacity of the second tank. Due to the larger net plots of the tied ridging treatment, three tanks were installed, so as to capture the anticipated larger volume of sediments.

2.4. Sampling Eroded Material. Rainfall data was collected from 1st of October through April of each year, which corresponds to the seasonal rainfall for this region. Tanks were emptied at the end of each storm unless the interval between storms was too short to allow emptying. Sediments and runoff (including the suspended material) collected from runoff plots were treated as different entities. Suspension was pumped out and subsampled for the determination of soil concentration in runoff, using the Hach spectrophotometer $\mathrm{DL} / 2000$. Later the sludge was transferred into 50 litre milk churns, topped up with water to a volume of 50 litres and weighed. The mass of oven dry soil, $M_{o}(\mathrm{~kg})$, was calculated using the following equation $[21,26]$ :

$$
M_{o}=1.7 \times\left(M_{s}-M_{w}\right),
$$

where $M_{s}$ is mass of fixed volume of sludge ( $\left.\mathrm{kg}\right), M_{w}$ is mass of the same volume full of water $(\mathrm{kg})$, and 1.7 is constant for the soil type.

2.5. Statistical Analysis. Data was analysed using Genstat 5 Release 1.3 for analysis of variance (ANOVA). Equations to estimate runoff, soil loss, and crop yield were developed for each tillage system using the climatic data and time factor, as climatic data is readily available and easily accessible to all and undoubtedly greatly influences agricultural production at any given area. Time also affects yield or soil degradation depending on the use of a particular piece of land. Therefore, while some other parameters, for example, soil moisture and crop cover are known to influence soil erosion and productivity of the soils, $[10,29]$ these have not been taken into consideration, yet this does not mean that their importance is not acknowledged.

Multiple regression analysis was carried out on the data collected over nine years to find factors that determine soil loss by sheet erosion from among rainfall amount, energy, and time. Four types of regression analysis were considered:

(i) standard regression with a forward selection of variables,

(ii) multiple regression on data after logarithmic and/or inverse transformation of the dependent variables,

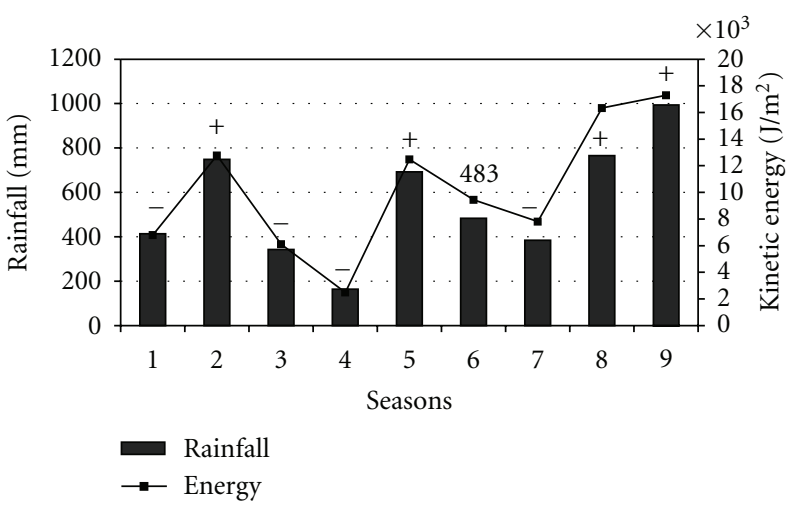

FIGURE 1: Seasonal rainfall energy and rainfall amount at Makoholi Contill site over nine seasons.

(iii) multiple regression after logarithmic transformation of the independent variables,

(iv) nonlinear regression analysis.

The transformations were done so as to fully explain the relationship of the dependent and independent variables as sometimes the relationship is not direct but logarithmic or exponential. Best-fit models were selected on the basis of the multiple regression coefficient $\left(R^{2}\right)$ of the bare fallow (for runoff and soil loss) and conventional tillage (for yield). To enable comparison among the different tillage systems the same set of variables was used across all tillage systems.

\section{Results}

3.1. Rainfall Amount, Distribution, and Intensity. Over the nine years seasonal rainfall ranged from $164 \mathrm{~mm}$ during the 4th year, (drought) to $994 \mathrm{~mm}$ during 9th season (Figure 1). The average calculated over these years was $554 \mathrm{~mm}$, which is well within the expected range for this natural region (450 to $650 \mathrm{~mm}$ ). However, Figure 1 shows that although the $554 \mathrm{~mm}$ is within the expected range, individual seasons lie outside this range. Only one season (year 6) was within $(483 \mathrm{~mm})$ the range, while all the other seasons lay on either side $(-;+)$ of the range (four seasons on each side). Apart from the fluctuations in the seasonal rainfall totals, monthly and daily rainfall distributions can also result in significant soil loss and runoff differences (Figure 2). Monthly rainfall totals, during the rainy seasons (October to April), ranged from 0 to $419 \mathrm{~mm}$ and daily rainfall from 0 to $182 \mathrm{~mm}$. The rainfall data collected also clearly shows that the rainy season usually starts in October and extends to April, while the growing season starts in November. The wettest months are December, January, and February. During six out of nine seasons, planting was carried out in November, two seasons in December, and one season in October.

Rainfall energy can be expressed as the erosive power of rainfall and was found to be closely associated with the rainfall amount (Figure 3). Correlating the two parameters gave a correlation's coefficient of $r=0.977$, indicating that the higher the rainfall amount, the higher the rainfall energy, that is, its erosive power. 


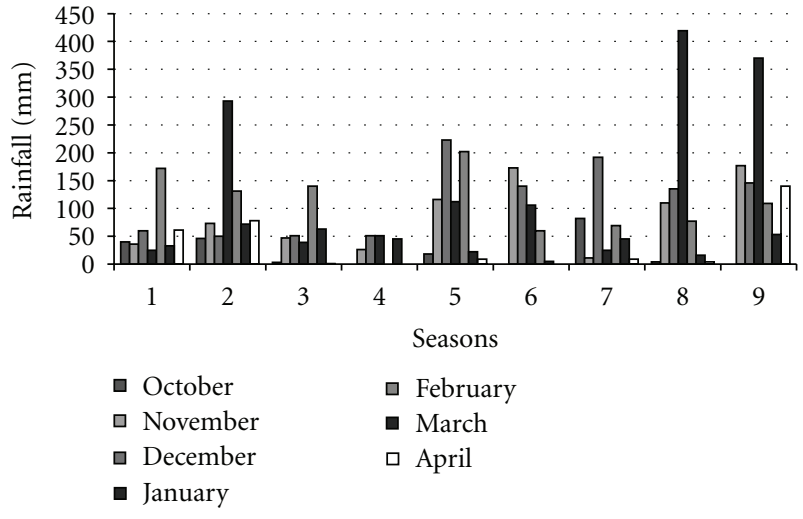

Figure 2: Monthly rainfall distribution over nine seasons at Makoholi Contill site.

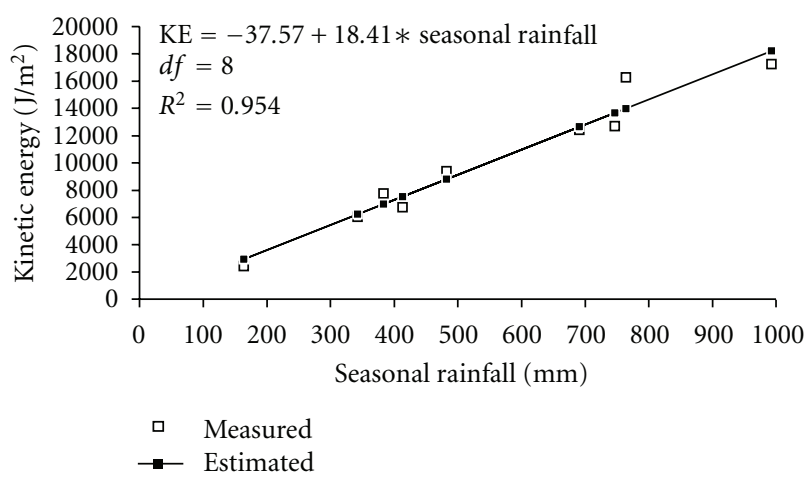

FIGURE 3: Correlation between seasonal rainfall amount and seasonal rainfall energy during nine seasons at Makoholi Contill site.

3.2. Runoff. There was a tendency for runoff to increase with the increase in the number of years of cultivation (Figure 4). The bare fallow had, as expected, the highest runoff average of $179 \mathrm{~mm} /$ ha over the nine years. On average, $32 \%$ of total rainfall received was lost as runoff, ranging between 17 and $43 \%$ over the nine-year period. Under this treatment-extreme conditions for accelerated erosion were created, giving the worst possible scenario under the given conditions. This treatment serves to show the erodibility of the soils under study. Among the cropped treatments, conventional tillage recorded the highest average runoff with a range of between 0.6 and $22 \%$ of total seasonal rainfall, while mulch ripping and tied ridging recorded the lowest runoff averages, which ranged from $0.3-15 \%$ and $0.0-11 \%$, respectively. As can be seen from Figure 4, the two systems have a lower cumulative runoff compared to conventional tillage. Runoff generated from the different treatments differed significantly at $P<0.001$. There was no significant difference between mulch ripping and tied ridging $(P=0.385)$. However, when the means of mulch ripping and tied ridging were compared with conventional tillage, the difference became significant at $P<0.001$. Year, rainfall, and energy were also considered as sources of variance. For all the treatments, there was a significant difference $(P<0.001)$

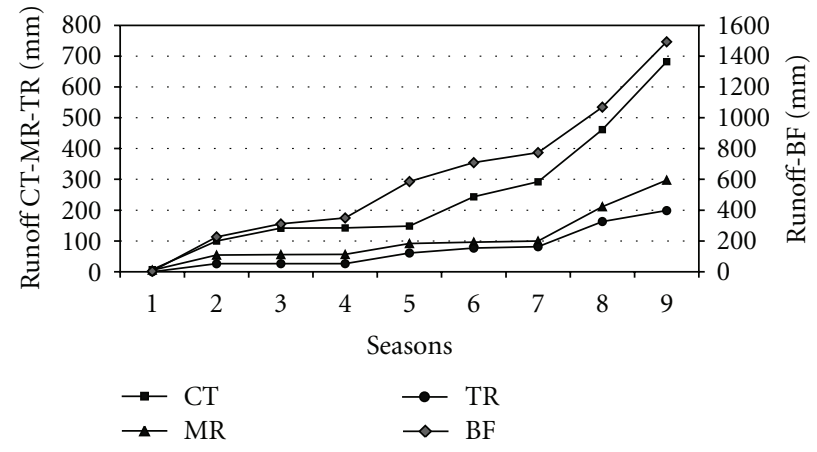

FIgure 4: Cumulative runoff ( $\mathrm{mm})$ under different tillage systems over nine seasons at Makoholi Contill site.

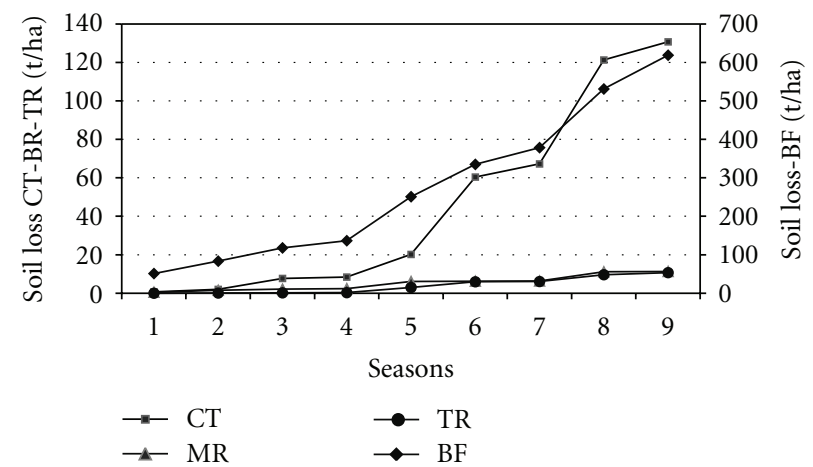

FIGURE 5: Soil losses under different tillage systems over nine seasons at Makoholi Contill site.

between the different years, rainfall amount, and rainfall energy.

3.3. Soil Loss. Soil losses under the bare fallow ranged from $9 \mathrm{t} /$ ha during the first year to $152 \mathrm{t} /$ ha during the 8 th year giving an average of $64 \mathrm{t} / \mathrm{ha} / \mathrm{yr}$ over the nine-year period. Conventional tillage recorded the highest cumulative soil losses among the cropped treatments (Figure 5) and averaged about $15 \mathrm{t} /$ ha over the nine seasons. Mulch ripping and tied ridging had, as expected, the lowest cumulative soil losses and proved to effectively conserve the soil. Analysis of variance showed the same trend as that of runoff, with differences between the treatments being significant at $P<$ 0.001. There was no significant difference between mulch ripping and tied ridging $(P=0.964)$. Once again the difference between the mean of mulch ripping and tied ridging varied significantly $(P<0.001)$ when compared to conventional tillage. As in runoff, the effects of year, rainfall amount, and energy on soil loss gave significant differences at $P<0.001$ for all the treatments except mulch ripping, where the variation was significant at $P<0.01$.

3.4. Maize Grain Yield. Yield ranged from $0 \mathrm{t} / \mathrm{h}$ a during drier seasons to more than $7 \mathrm{t} /$ ha during years with abundant rainfall. Mulch ripping had the highest cumulative yield and averaged (3.5t/ha) over the nine years (Figure 6). Conventional tillage gave an average yield of $3.0 \mathrm{t} / \mathrm{ha}$ and tied 


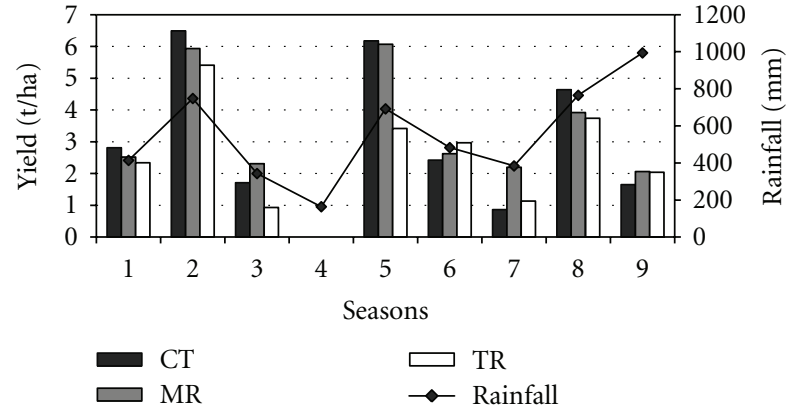

Figure 6: Maize yield under different tillage systems over nine seasons at Makoholi Contill site.

ridging recorded the lowest cumulative crop yield with an average of $2.6 \mathrm{t} / \mathrm{ha}$. Maize grain yields under the different tillage systems did not differ significantly from one another $(P=0.497)$. Crop yields resulted in significant treatment differences only during somewhat drier seasons, or seasons characterised by poor rainfall distribution, for example, during the 7th season; yield gave a significant treatment difference at $P<0.025$. Mulch ripping and tied ridging also differed significantly at $P<0.025$. The different years with different rainfall amounts caused a variation in maize yield resulting in significant differences between years $(P<0.001)$ for all the treatments.

3.5. Developing Simple Equations. The high correlation between rainfall amount and rainfall energy $(r=0.977)$ left very little room from which to choose one parameter in place of the other, meaning that the two parameters can be interchanged. Therefore, if rainfall energy data is not available, rainfall amount can be used with negligible effect on the coefficient of determination $\left(R^{2}\right)$.

The following parameters were used in the equations:

RO: total seasonal runoff ( $\mathrm{mm}$ ),

SL: total seasonal soil loss $(\mathrm{kg} / \mathrm{ha})$,

YI: seasonal maize grain yield ( $\mathrm{t} / \mathrm{ha}$ ),

ENER: total seasonal rainfall energy $\left(\mathrm{J} / \mathrm{m}^{2}\right)$,

nYEARS: number of years of cultivation,

RAIN: total seasonal rainfall amount (mm).

3.6. Runoff Equations. The following equation was used for the determination of runoff:

$$
\mathrm{RO}=a+b X_{1}+c \operatorname{EXP}\left(X_{2}\right)
$$

where $a$ is constant; $b$ and $c$ are coefficients; $X_{1}$ is ENER; $X_{2}$ is nYEARS.

Runoff under the bare fallow was estimated to increase directly with increasing rainfall energy (Table 1) at $19 \mathrm{~mm} /$ $1000 \mathrm{~kJ} / \mathrm{m}^{2}$. Runoff also increased exponentially to the year, whereby the estimated runoff during the first year was $156 \mathrm{~mm} / 10000 \mathrm{~kJ} / \mathrm{m}^{2}$ and by the ninth year it was estimated to be $272 \mathrm{~mm} / 10000 \mathrm{~kJ} / \mathrm{m}^{2}$. With an $R^{2}$ value of 0.92 , runoff
TABLE 1: The effect of rainfall energy and number of years of cultivation on runoff under different tillage systems at Makoholi Contill site.

\begin{tabular}{lcccc}
\hline Treatment & Constant & Energy & Exp. nYears & $R^{2}$ \\
\hline Bare fallow & -30.0 & 0.01856 & 0.01437 & 0.92 \\
Conv. tillage & -26.9 & 0.00987 & 0.00960 & 0.80 \\
Mulch ripping & -36.1 & 0.00661 & 0.00213 & 0.66 \\
Tied ridging & -29.4 & 0.005377 & -0.00223 & 0.67 \\
\hline
\end{tabular}

from the bare fallow can be confidently predicted using rainfall energy and the number of years of cultivation.

Under cropped treatments, runoff was estimated to increase directly with the increase in rainfall energy at about $10 \mathrm{~mm} / 1000 \mathrm{~kJ} / \mathrm{m}^{2}$ under conventional tillage, $6.6 \mathrm{~mm} / 1000 \mathrm{~kJ} / \mathrm{m}^{2}$ under mulch ripping, and $5.4 \mathrm{~mm} /$ $1000 \mathrm{~kJ} / \mathrm{m}^{2}$ under tied ridging. It was also predicted to increase from about $72 \mathrm{~mm} / 10000 \mathrm{~kJ} / \mathrm{m}^{2}$ during the first year of cultivation to about $150 \mathrm{~mm} / 10000 \mathrm{~kJ} / \mathrm{m}^{2}$ during the ninth year under conventional tillage, from $30 \mathrm{~mm} /$ $10000 \mathrm{~kJ} / \mathrm{m}^{2}$ to $47 \mathrm{~mm} / 10000 \mathrm{~kJ} / \mathrm{m}^{2}$ under mulch ripping and decrease from $25 \mathrm{~mm} / 10000 \mathrm{~kJ} / \mathrm{m}^{2}$ to $6.3 \mathrm{~mm} /$ $10000 \mathrm{~kJ} / \mathrm{m}^{2}$ under tied ridging. Thus runoff under conventional tillage was estimated to increase by $78 \mathrm{~mm}$ from the first year to the ninth year and by a mere $17 \mathrm{~mm}$ under mulch ripping for the same period. This increase under mulch ripping was generally a result of high runoff recorded during wet years, where the soil under the mulch was saturated (high infiltration and reduced evaporative losses). However, when rainfall amount was normal and well distributed, runoff tended to decrease with the number of years of cultivation, that is, the cumulative effect of mulch. Runoff under tied ridging was estimated to decrease by $16 \mathrm{~mm}$ over nine years. This is largely due to increased infiltration in the microdams which then reduces runoff. The $R^{2}$ value of 0.80 under conventional tillage is also high enough to allow for runoff to be confidently predicted using these two parameters (rainfall energy and the number of years of cultivation).

3.7. Soil Loss Equations. The following equation was used for the estimation of soil loss:

$$
\mathrm{SL}=a+b X_{1}+c X_{2},
$$

where $a$ is constant, $b$ and $c$ are coefficients, $X_{1}$ is nYEARS, $X_{2}$ is ENER.

Under the bare fallow, the variables year and energy (Table 2) were the most descriptive ones. This was expected, as there was no ground cover to intercept rainfall energy. Soil loss was estimated to increase by $7.3 \mathrm{t} / \mathrm{ha}$ with the increase in the number of years of cultivation and by $5.1 \mathrm{t} / \mathrm{ha} / 1000 \mathrm{~kJ} / \mathrm{m}^{2}$ rainfall energy. These variables explained $60 \%$ of the variation of soil loss. Using the same parameters as for the bare fallow, soil loss under the cropped treatments was estimated to increase by $2.9 \mathrm{t} / \mathrm{ha}$ under conventional tillage, decrease by $0.1 \mathrm{t} / \mathrm{ha}$ under mulch ripping, and increase by $0.2 \mathrm{t} / \mathrm{ha}$ under tied ridging with every increase in the number of years 
TABLE 2: The effect of rainfall energy and number of years of cultivation on soil loss under different tillage systems at Makoholi Contill site.

\begin{tabular}{lcccc}
\hline Treatment & Constant & nYears & Energy & $R^{2}$ \\
\hline Bare fallow & -23.6 & 7.28 & 0.00505 & 0.60 \\
Conv. tillage & -8.78 & 2.92 & 0.000869 & 0.25 \\
Mulch ripping & -0.173 & -0.113 & 0.000205 & 0.09 \\
Tied ridging & -0.766 & 0.166 & 0.0001129 & 0.27 \\
\hline
\end{tabular}

TABLE 3: The effect of rainfall amount and number of years of cultivation on maize yield under different tillage systems at Makoholi Contill site.

\begin{tabular}{lccccc}
\hline Treatment & Constant & Exp. nYear & Rainfall & $R^{2}$ & $\begin{array}{c}\text { Signif. } \\
\text { level }\end{array}$ \\
\hline Conv. tillage & -2.241 & -0.0009493 & 0.011821 & 0.90 & $P<0.001$ \\
Mulch ripping & -1.689 & -0.0010092 & 0.011882 & 0.85 & $P<0.001$ \\
Tied ridging & -1.382 & -0.0006357 & 0.008736 & 0.82 & $P<0.025$ \\
\hline
\end{tabular}

of cultivation. Soil loss also tended to increase by $0.9 \mathrm{t} / \mathrm{ha}$ under conventional tillage, $0.2 \mathrm{t} / \mathrm{ha}$ under mulch ripping, and $0.1 \mathrm{t} /$ ha with every $1000 \mathrm{~kJ} / \mathrm{m}^{2}$ increase in rainfall energy.

The $R^{2}$ values were very low explaining only $25 \%$ of the variation under conventional tillage, $9 \%$ under mulch ripping, and $27 \%$ under tied ridging. While for all the treatments, increases in soil loss are given in relation to 1000 $\mathrm{J} / \mathrm{m}^{2}$; it should be noted that the average rainfall energy over the nine years is more than ten times this value, that is, 10 $166 \mathrm{~J} / \mathrm{m}^{2}$.

3.8. Yield Equations. Yield was closely related to rainfall $(P<0.001)$ and was related exponentially to the year, for all treatments. The following equation was used for the determination of yield:

$$
\mathrm{YI}=a+b \operatorname{EXP}\left(X_{1}\right)+c X_{2},
$$

where $a$ is constant; $b$ and $c$ are coefficient; $X_{1}$ is nYEARS; $X_{2}$ is RAIN.

Under conventional tillage, yields were poorly and negatively correlated to year $(-0.195)$, while better correlated to rainfall amount $(0.551)$. The maize grain was estimated to increase by $1.2 \mathrm{t} / \mathrm{ha}$ for every $100 \mathrm{~mm}$ of rainfall received (Table 3). The highest yields were predicted under mulch ripping. A low and negative $r$ value was also found between yield and year $(-0.241)$, meaning that there is a decrease in yield with time. The correlation between yield and rainfall was lower than under conventional tillage (0.488). Crop yields were predicted to increase at $1.3 \mathrm{t} /$ ha for every $100 \mathrm{~mm}$ of rainfall received. Yields under tied ridging were estimated to increase at $0.9 \mathrm{t} /$ ha for every $100 \mathrm{~mm}$ of rainfall and also decrease exponentially to the year.

\section{Discussion}

The nine years data showed the erratic and unreliable nature of rainfall, both between and within the seasons, in the semiarid region of southern Zimbabwe. Within the nine years of research, seasonal rainfall varied extensively from $164 \mathrm{~mm}$ to $994 \mathrm{~mm}$. While the average rainfall amount $(554 \mathrm{~mm})$ still lay within the given range for this natural region (450$650 \mathrm{~mm} / \mathrm{yr}$ ), only one season recorded a seasonal total within this range and the other eight seasons recorded either higher or lower seasonal totals. The monthly and daily totals were equally variable, with some months recording much more than seasonal totals and some days recording more than monthly totals. This great variation in rainfall poses a high risk in agricultural production, as it becomes difficult to predict rainfall for any one season with certainty [15]. The erratic nature of rainfall also adds to the erosion problem [2]. Hudson [30] and Elwell and Stocking [31] reported that the rare and infrequent heavy storms cause severe erosion. The infiltration capacity of the soils, during such storms is exceeded and the high intensity causes crust formation [8], which leads to high runoff and soil losses.

The study results showed very high runoff and soil losses under the bare fallow and conventional tillage systems and negligible losses under mulch ripping and tied ridging. When the natural equilibrium of the soil is disturbed through cultivation-disruption of soil aggregates and increased aeration-the rate of organic matter mineralization is increased [32-34]. Organic matter is important in the soil aggregation and improves water infiltration and storage [35], thus its reduction results in higher rates of soil erosion. The very high topsoil losses with conventional tillage will eventually result in reduced plant available water and nutrients and thus productivity, as the soil depth is limited due to the presence of a stone line at around $50-80 \mathrm{~cm}$ depth [21]. Although plant nutrients can be compensated by additions of fertiliser or manure, in rain-fed agriculture, plant available water cannot be ameliorated. The physical properties, therefore, altered (e.g., water holding capacity) by soil erosion, are the most long term yield limiting factors [36]. Mulch ripping and tied ridging proved to be effective in reducing soil erosion. The mulch intercepts rainfall energy, thus increasing infiltration [37-39], while the rotting stover adds organic matter to the soil $[40,41]$. The microdams under tied ridging enhance water ponding thus increasing water storage and reducing drainage [7]. The regression equations also support the dependence of runoff primarily on rainfall energy and the number of years of cultivation, $R^{2}=0.92$ for bare fallow and $R^{2}=0.80$ for conventional tillage. The $R^{2}$ values for the estimation of soil loss were generally lower than those found for the estimation of runoff, indicating that soil loss is also affected by other factors other than rainfall energy and time. Crop or ground cover and runoff volume and velocity have to be considered as well [40]. The ground cover effect is especially important under mulch ripping, while runoff volume and velocity are also drastically reduced under mulch ripping and tied ridging.

Mulch ripping had the highest yield average of $3.5 \mathrm{t} / \mathrm{ha}$ due to lower evaporative losses, especially during years with low rainfall or poor rainfall distribution. The soil moisture conserved ensured a better water supply to the crop during mid-season dry spells. Although runoff was drastically reduced under tied ridging, the water harvested in the microdams quickly drained away due to the very 
high infiltration capacity, $40 \mathrm{~cm} / \mathrm{h}$ according to Vogel [21], and low water holding capacity of these soils, which was found by Moyo and Hagmann [42] to be $10.3 \%$ by volume. Therefore, when rainfall events were widely spaced, the water harvested in micro-dams did not benefit the crop, as it would have drained away. The soil surface was also increased through ridging, thereby increasing evaporative losses [42]. The variables rainfall amount and time were found to adequately estimate yield; $R^{2}$ values ranged from 0.82 to 0.94 across all treatments. There was a direct linear relationship between yield and rainfall amount and maize grain yield increased by 0.9 (tied ridging), 1.2 (conventional tillage), and $1.3 \mathrm{t} / \mathrm{ha}$ (mulch ripping) with every $100 \mathrm{~mm}$ increment of rainfall. Yields decreased exponentially to the year under all the treatments indicating the reduction of productivity as soils are opened from virgin land.

Although the sandy soils are described as inherently infertile [43], the applied fertilisers seem to be adequate resulting in high yields during good rainfall seasons. Thus, rainfall, more than fertility, seems to be the most important yield-limiting factor. The study did not establish any conclusive yield variation among the treatments, except that under all tillage systems, there was a yield decline with the number of years of cultivation. Thus optimal fertiliser application and use of hybrid seed mask the effect of erosion on yield, as optimal crop growth can be achieved, if weather conditions are favourable. Thus, the fertiliser application is very much dependent on rainfall, so that rainfall becomes the most important factor influencing crop production. The effect of erosion on yield is of long term, while rainfall-thus soil moisture content-is the main short-term factor that influences yield.

\section{Conclusions}

The results of this study led to the following conclusions.

(i) Mulch ripping is the recommended tillage system for conserving soil and water and sustaining yields, while tied ridging can also be used satisfactorily to conserve soil and water but should be combined with mulch for better yields.

(ii) Conventional tillage practiced in the communal areas has to be replaced by conservation tillage techniques so as to reduce soil and water losses and maintain soil productivity.

(iii) Runoff and soil losses are a function of rainfall amount and intensity, number of years of cultivation and ground cover, that is, ploughing or minimum tillage; bare soil or soil covered with crops, weeds or mulch. The lower the intensity of tillage and the higher the ground cover, the better.

(iv) In semiarid regions where rainfall is limiting, yield is mostly dependent on the amount of rainfall and period of cultivation rather than fertility, if optimal fertilisers are used.

(v) Yield is a poor indicator of soil erosion when fertilisers and hybrid varieties are used as yield decline is masked. This is likely to be the case until such a time that yield declines even with the use of fertilisers and better cultivars, at which stage the damage might well be irreversible.

\section{Acknowledgments}

The author would like to express gratitude to GTZ for providing the much needed funding through CONTILL (Conservation Tillage), a collaborative project between GTZ and the Government of Zimbabwe (GoZ). Further acknowledgement goes to the GoZ, for providing the opportunity and research facilities. The author would like to thank all the CONTILL members from both Domboshawa and especially Makoholi site for their relentless support and input towards the success of this project.

\section{References}

[1] H. A. Elwell, "Sheet erosion from arable lands in Zimbabwe: prediction and control," in Harare Symposium on Soil and Water Conservation, pp. 429-438, Harare Zimbabwe, IAE, 1984.

[2] F. R. Troeh, J. A. Hobbs, and R. L. Donahue, Soil and Water Conservation for Productivity and Environmental Protection, Prentice-Hall, Englewood Cliffs, NJ, USA, 1980.

[3] J. Poesen and J. Savat, "Particle size separation during erosion by splash and runoff," in Assessment of Erosion, M. de Boodt and D. Gabriels, Eds., pp. 427-440, Wiley, Chichester, UK, 1980.

[4] R. Lal, "Monitoring soil erosion's impact on crop productivity," Soil Erosion Research Methods, pp. 187-201, 1988.

[5] R. J. Godwin, Agricultural Engineering in Development: Tillage for Crop Production in Areas of Low Rainfall, vol. 83, FAO Agricultural Services Bulletin, Rome, Italy, 1990.

[6] M. Stocking and L. Peake, "Soil conservation and productivity," in Proceedings of the 4th International Conference on Soil Conservation, pp. 399-438, University of Venezuale, Maracay, Venezuela, November 1985.

[7] N. W. Hudson, Land Husbandry, Batsford, London, UK, 1992.

[8] D. K. Cassel, C. W. Raczkowski, and H. P. Denton, "Tillage effects on corn production and soil physical conditions," Soil Science Society of America Journal, vol. 59, no. 5, pp. 1436$1443,1995$.

[9] G. Wrigley, Tropical Agriculture: The Development and Production, Macmillan Publishing, New York, NY, USA, 1992.

[10] Y. Le Bissonnais and M. J. Singer, "Crusting, runoff, and erosion response to soil water content and successive rainfalls," Soil Science Society of America Bulletin, vol. 56, no. 6, pp. 18981903, 1992.

[11] M. H. Beare, P. F. Hendrix, and D. C. Coleman, "Water-stable aggregates and organic matter fractions in conventional- and no-tillage soils," Soil Science Society of America Journal, vol. 58, no. 3, pp. 777-786, 1994.

[12] R. P. C. Morgan, Soil Erosion and Conservation, Longman Group UK Limited, Harlow, UK, 1986.

[13] H. A. Elwell, "Feasibility of modelling annual soil loss, runoff and maize yiled for the two research sites, Domboshawa and Makoholi. Projections to other natural regions in Zimbabwe. Testing of and contributions to SLEMSA," Consultancy Report, AGRITEX/ GTZ Conservation Tillage Project IAE, Harare, Zimbabwe, 1994. 
[14] P.M. Grant, "Peasant farming on infertile sands," Rhodesian Science News, vol. 10, no. 10, pp. 252-254, 1976.

[15] S. Moyo, P. Robinson, Y. Katerere, S. Stevenson, and S. Gombo, Zimbabwe's Environmental Dilemma. Balancing Resource Inequities, ZERO, Harare, Zimbabwe, 1991.

[16] F. B. S. Kaihura, I. K. Kullaya, M. Kilasara, J. B. Aune, B. R. Singh, and R. Lal, "Impact of soil erosion on soil productivity and crop yield in Tanzania," Advances in GeoEcology, vol. 31, pp. 375-381, 1998.

[17] M. Rosenberg, "Koeppen climate classification," 2007, http:// geography.about.com/od/physical geography/a/koeppen.htm.

[18] MNTR, The National Conservation Strategy, Zimbabwe's Road to Survival, The Government of Zimbabwe, Harare, Zimbabwe, 1987.

[19] J. G. Thompson and W. D. Purves, A Guide to the Soils of Rhodesia, vol. 1, Department of Research and Specialist Services, Harare, Zimbabwe, 1978.

[20] K. Nyamapfene, Soils of Zimbabwe, Nehanda Publishers, Harare, Zimbabwe, 1991.

[21] H. Vogel, "An evaluation of five tillage systems from smallholder agriculture in Zimbabwe," Landwirtschaft der Tropen, vol. 94, pp. 21-36, 1993.

[22] Anon, Guide to Makoholi Experiment Station, Department of Research and Specialist Services, Salisbury, UK, 1969.

[23] J. G. Thompson, Report on the Soils of the Makoholi Experiment Station, Department of Research and Specialist Services, Salisbury, UK, 1967.

[24] J. G. Thompson and W. D. Purves, A Guide to the Soils of Zimbabwe, vol. 3, Department of Research and Specialist Services, CHarare, Zimbabwe, 1981.

[25] CONTILL, "Conservation tillage for sustainable crop production systems," Working Document, IAE, Harare, Zimbabwe, 1990.

[26] F. E. Wendelaar and A. N. Purkis, "Recording soil loss and runoff from $300 \mathrm{~m}^{2}$ erosion research field plots," Research Bulletin 24, Conex, Harare, Zimbabwe, 1979.

[27] A. Moyo, Assessment of the effect of soil erosion on nutrient loss from granite-derived sandy soils under different tillage systems in Zimbabwe, Ph.D. thesis, 2003.

[28] A. Munodawafa, "Assessing nutrient losses with soil erosion under different tillage systems and their implications on water quality," Physics and Chemistry of the Earth, vol. 32, no. 15-18, pp. 1135-1140, 2007.

[29] K. J. Olsen, "Modelling runoff and soil loss on coarse grained sandy soils at Domboshawa, Zimbabwe," Contill Project Research Report 12, IAE, Harare Zimbabwe, 1994.

[30] N. W. Hudson, Erosion Research. Advisory Notes, Conex, Salisbury, UK, 1958.

[31] H. A. Elwell and M. A. Stocking, "Rainfall parameters and a cover model to predict runoff and soil loss from grazing trials in the Rhodesian sandveld," Grasslands Society for Southern Africa, vol. 9, pp. 157-164, 1974.

[32] D. Schroeder, Soils. Facts and Concepts, FHAG, Berne, Switzerland, 1984.

[33] J. R. Salinas-Garcia, F. M. Hons, and J. E. Matocha, "Longterm effects of tillage and fertilization on soil organic matter dynamics," Soil Science Society of America Journal, vol. 61, no. 1, pp. 152-159, 1997.

[34] D. A. Angers, A. N'dayegamiye, and D. Cote, "Tillage-induced differences in organic matter of particle-size fractions and microbial biomass," Soil Science Society of America Journal, vol. 57, no. 2, pp. 512-516, 1993.

[35] R. H. Follett, S. C. Gupta, and P. G. Hunt, "Conservation practices: relation to the management of plant nutrients for crop production," in Soil Fertility and Organic Matter as Critical Components of Production Systems, pp. 19-51, Journal of Soil Science Society of America, Special Publication 19, Madison, Wis, USA, 1987.

[36] B. Lowery and W. E. Larson, "Erosion impact on soil productivity," Journal of Soil Science Society of America, vol. 59, no. 3, pp. 647-648, 1995.

[37] J. E. Adams, "Influence of mulches on runoff, erosion and soil moisture depletion," Proceedings of Soil Science Society of America, vol. 30, pp. 110-114, 1966.

[38] P. G. Braithwaite, "Conservation tillage- planting systems," Rhodesian Farmer, vol. 10, pp. 25-32, 1976.

[39] H. A. Elwell, "An assessment of soil erosion in Zimbabwe," Zimbabwe Science News, vol. 19, no. 3-4, pp. 27-31, 1986.

[40] W. L. Hargrove, "Crop residue management in the SouthEast," in Proceedings of the National Conference on Crop Residue Management for Conservation, Lexington, Ky, USA, 1991.

[41] D. C. Reicosky, W. D. Kemper, G. W. Langdale, C. L. Douglas, and P. E. Rasmussen, "Soil organic matter changes resulting from tillage and biomass production," Journal of Soil and Water Conservation, vol. 50, no. 3, pp. 253-261, 1995.

[42] A. Moyo and J. Hagmann, "Growth-effective rainfall in maize production under different tillage systems in semi arid conditions and shallow granitic sands of Southern Zimbabwe," in Proceedings of the 13th International Soil Tillage Research Organisation, Aalborg, Denmark, July 1994.

[43] P. Grant, "Peasant farming on infertile sands," in The Rhodesia Science News, vol. 10, pp. 252-254, Rhodesia Scientific Association, Harare, Zimbabwe, 10 edition, 1981. 

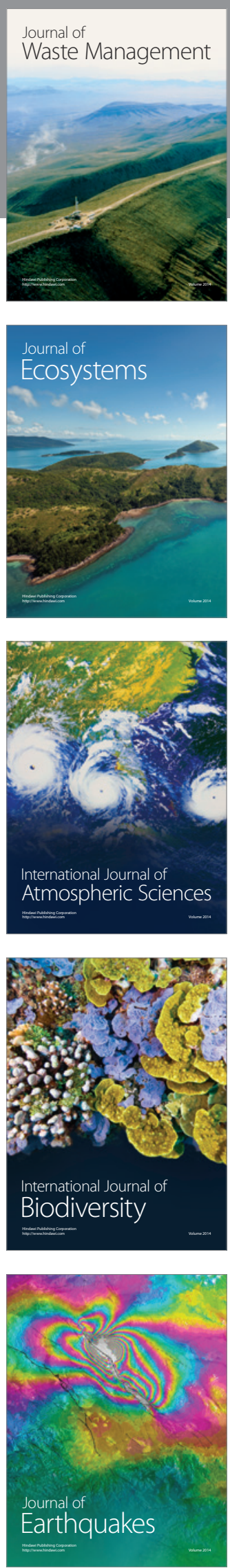
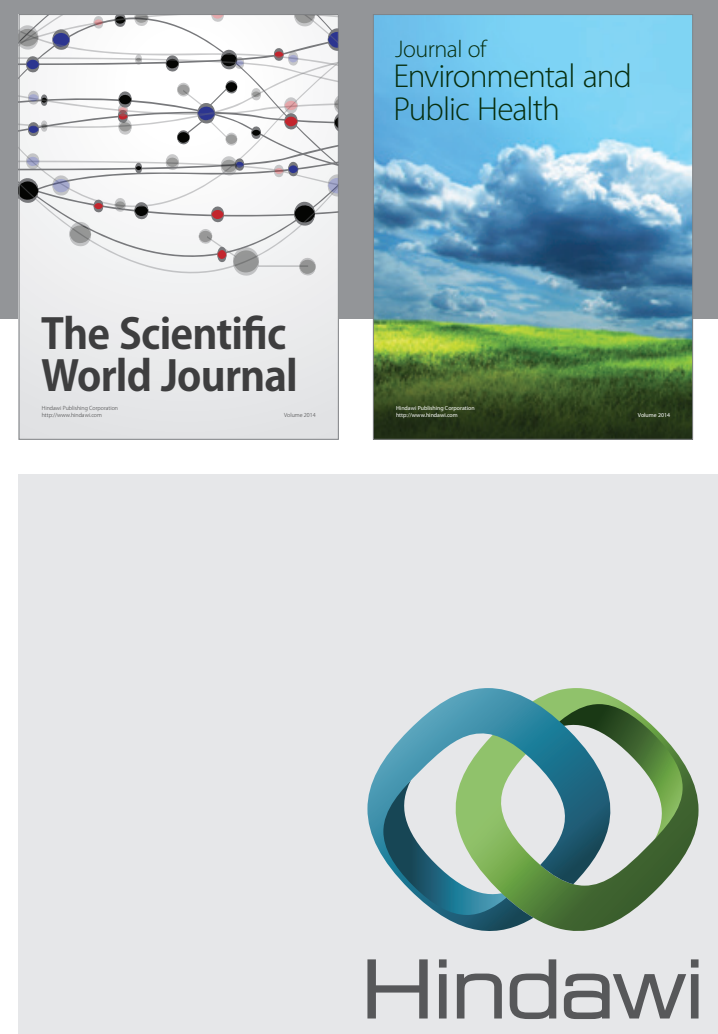

Submit your manuscripts at

http://www.hindawi.com
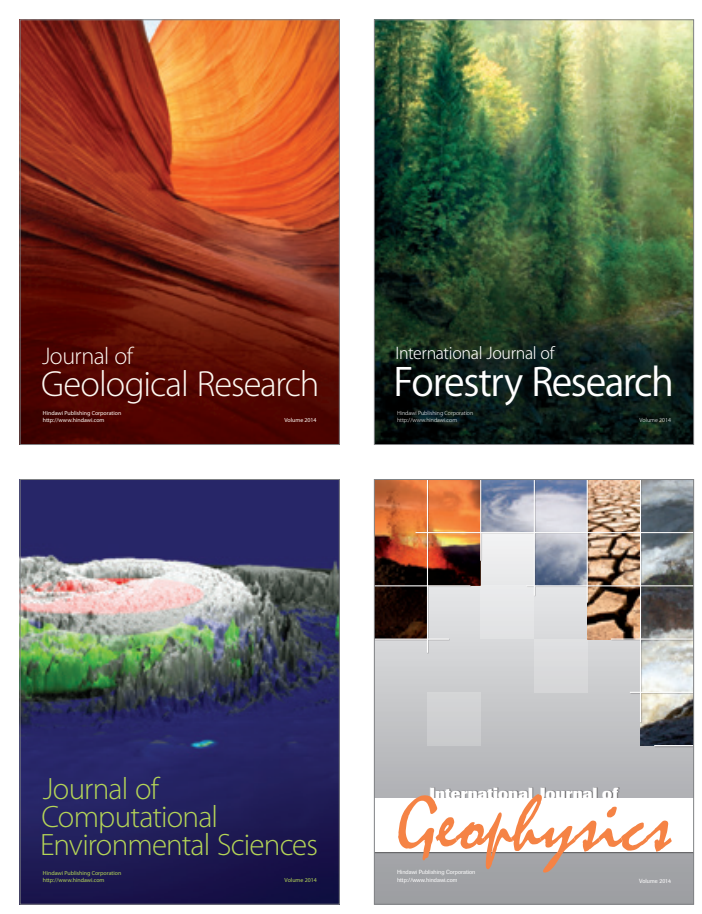
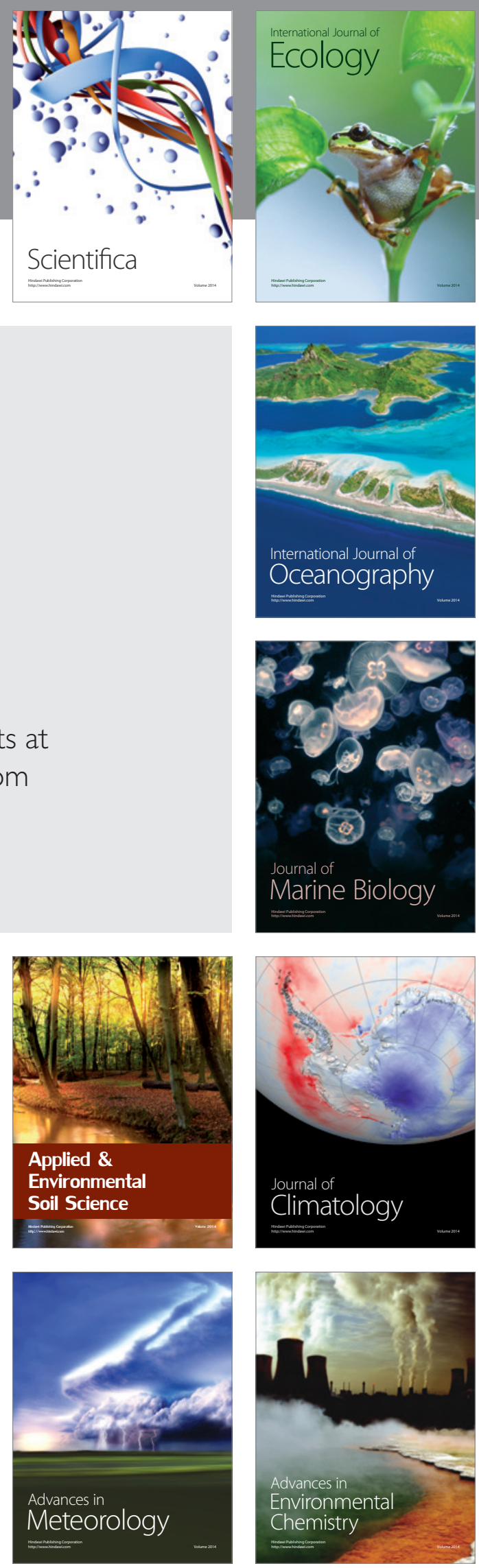